\title{
Professional Ethics of Social Entrepreneurs: The Perspective of Christian Personalist Ethics ${ }^{1}$
}

\author{
ADAM ZADROGA \\ Katolicki Uniwersytet Lubelski Jana Pawła II \\ zadroga@kul.pl, ORCID 0000-0002-1706-9106
}

\begin{abstract}
The aim of the article is to indicate and describe the normative assumptions of the professional ethics of social entrepreneurs. The innovative nature of the proposed concept consists in taking into consideration the perspective of Christian personalist ethics. It is a theory of morality which includes considerations for the biblical and theological view of man, emphasizing above all their personal dignity. Referring to the principal axioms of this ethical doctrine allows for a presentation of a proposal of ethical principles and moral virtues - adequate to the mission, tasks, and vocation of social entrepreneurs. The article discusses the following issues: the essence of Christian personalist ethics, the mission and tasks of social entrepreneurs, the motivation and vocation of social entrepreneurs, ethical aspects of leadership in social enterprises, as well as the ethical principles and moral virtues of social entrepreneurs. A methodology characteristic of normative philosophical ethics and moral theology was applied. The results of the analysis of the methodically selected literature on the subject were processed by means of conceptual work, which allowed us to describe the professional ethics of social entrepreneurs from the point of view of Christian personalist ethics. Christian personalist ethics makes a valuable and original contribution to the description of the normative determinants of social entrepreneurship. The analysis of the mission and tasks of social entrepreneurs shows that they create social structures and processes that affirm the dignity of marginalized people and restore their capacity to participate in social and economic life.
\end{abstract}

Keywords: Christian personalist ethics, leadership, professional ethics, social entrepreneurship, social entrepreneur

Among those who undertake business activity, a certain distinct group can be distinguished, namely, social entrepreneurs. These are people whose motivation for activity differs from that of typical businessmen (commercial entrepreneurs). Similarly, the goals set by them for their activities are of different character. For commercial entrepreneurs, the paramount objective is to increase the market value of their private companies and to multiply personal wealth with the profits achieved. In contrast, the main idea of social entrepreneurship is the attainment of social goals - introducing positive solutions for individuals in need of support but also for the society (especially the local community), and for the preservation of the natural environment.

1 This publication is the result of a research project financed by the National Science Center, Poland registration No. 2017/25/B/HS1/01522. 
In the first case, the social goal is largely related to the problem of social exclusion and the difficulties faced by people threatened with marginalization (e.g., the disabled, former prisoners, long-term unemployed, refugees) with respect to finding suitable employment. Besides, as previously indicated, social entrepreneurs may also engage in issues related to local development and environmental challenges. ${ }^{2}$ The originality of the approach of social entrepreneurs in their efforts to introduce positive social changes lies in the fact that their solutions are based on the mechanisms and means which are utilized in the classic entrepreneurship - the achieved financial results are allocated to the implementation of the aforementioned social goals. In order to pursue the idea indicated in practice, basing on an innovative concept, they establish and run social enterprises which, due to their organizational and legal character, allow them to operate "at the interface" of the market, social and public sectors. ${ }^{3}$ Notwithstanding the broad definition-oriented discussion concerning the concept of "social enterprise," 4 it should be emphasized that social entrepreneurship has three most important features: 1) social reason for activity, 2) clearly profitable form of activity serving the implementation of a social goal, and 3) innovative nature of the enterprise. Generally speaking, three dominant schools of defining social enterprise can be identified: earned income, social innovation, and EMES. ${ }^{5}$

Currently, increased interest in social entrepreneurship is observed not only among social activists, but also researchers. ${ }^{6}$ The former sees it as an opportunity to compensate for the unreliability of the existing solutions based on the social policy of the state, welfare system, and standard methods used in social work practice. The latter, appreciating its practical values, emphasize that even - the best practice - requires deeper theoretical foundations. Various scientific studies serve this pur-

2 It is worth noting that social entrepreneurs, through their activities in the indicated areas, implement the so-called sustainable development goals formulated in the document adopted by the resolution of the UN General Assembly on 25 September 2015 entitled "Transforming Our World: the 2030 Agenda for Sustainable Development."

3 Murzyn - Pach, Ekonomia społeczna.

4 One should be aware, however, that social entrepreneurship is a very complex phenomenon, and the term "social enterprise" is often used in the literature as an umbrella term for various types of social initiatives as well as diverse organizational and legal forms. Moreover, in individual countries or regions of the world, the concept of a social enterprise covers various forms, also from the point of view of particular goals or development paths of social enterprises. Therefore, as Marzena Starnowska notes, a social enterprise "is the most universal term representing what goes on in social entrepreneurship because it does not apply to any specific sector and does not indicate any specific organizational and legal form" (Starnawska, "Przedsiębiorczość społeczna w społeczeństwie obywatelskim w Polsce," 172-173). Cf. also: Ciepielewska-Kowalik et al., Social Enterprise in Poland.

5 The first two approaches come from the United States, and the third concept has emerged in Europe as a result of the research work of the EMES network (a research network of collaborating universities and researchers from Europe who undertake research on social enterprises and social entrepreneurship see more at www.emes.net).

6 Chell et al., "Social Entrepreneurship and Business Ethics," 619; Mair - Robinson - Hockerts, Przedsiębiorczość społeczna. 
pose. $^{7}$ Naturally, among them one finds ethical analyses and evaluations; after all, man - as a free and rational being - remains an entity subject to moral judgment in every sphere of their activity, even if their activity serves others. However, this aspect of the scientific discourse in relation to social entrepreneurship is rarely addressed. ${ }^{8}$ This scarcity of research probably stems from the assumption held by some researchers whereby since this activity is, among others, of a socially assistive character, then it is - in principle - ethically correct, and therefore, it does not require a more indepth moral reflection. The result of this erroneous view is the still unsatisfactory state of research ${ }^{9}$ describing ethical determinants of social entrepreneurship.

Another problem is that the authors of the existing, albeit scarce, publications dealing with the indicated issues refer to various approaches toward normative ethics, such as Kantian ethics, utilitarianism, the ethics of virtues, the ethics of discourse, postmodern ethics, the ethics of care, etc. Yet, the subject matter has not been explored from the point of view of Christian personalist ethics. Hence, this research perspective is adopted in the process of analyzing and constructing the concept of the professional ethics of social entrepreneurs.

The main aim of the paper is to indicate and describe the normative assumptions of the professional ethics of social entrepreneurs. The unconventional nature of the proposed research concept pivots on Christian personalist ethics as a point of reference. It is a theory of morality which includes considerations for the biblical and theological view of man, emphasizing above all their personal dignity. Moreover, reference to the principal axioms of this ethical doctrine allows for a presentation of a proposal of ethical principles and moral virtues - adequate to the mission, tasks, and vocation of social entrepreneurs.

The research employed a method characteristic of normative philosophical ethics and moral theology: the content of the selected literature on the subject has been analyzed, and its outcome has been subjected to inference and conceptual elaboration. The selection of publications for analysis has been made according to the criterion of usability for conducting a study of the following specific issues: the essence of Christian personalist ethics, the mission and tasks of social entrepreneurs, the motivation and vocation of social entrepreneurs, ethical aspects of leadership in social enterprises as well as the principles of professional ethics and moral virtues of social entrepreneurs. Ultimately, the study has allowed for presenting the concept of professional ethics of social entrepreneurs from the point of view of Christian personalist ethics.

Hota - Subramanian - Narayanamurthy, "Mapping the Intellectual Structure," 20.

Cornelius et al., "Corporate Social Responsibility"; Chell et al., "Social Entrepreneurship and Business Ethics," 621.

9 See more: Zadroga, "Methodological Premises"; Chell et al., "Social Entrepreneurship and Business Ethics." 


\section{The Essence of Christian Personalist Ethics}

A variety of ethics based on the recognition of and respect for the dignity of every human is termed personalist ethics. Usually, it is indicated as Christian personalist ethic. This is because the Greek term persona (person) is closely related to the formation of the theological teaching about Jesus Christ as God and Man in one Divine Person and about One God in Three Persons. Christian morality is also of personalist character because the entire Christian theology is of personalist character as it is concerned with personal God and man as a person who is spiritually linked to Him. It is the morality of man created in the image and likeness of God (Gen 1:27) and the morality of man believing in Christ who, through his Incarnation, became spiritually linked with every human being. ${ }^{10}$

Hence, the Catholic Church paces man at the center of her entire moral teaching. Before discussing this issue in detail, it is worth recalling that in moral theology as a result of - influenced by the Second Vatican Council - the method of ethical regulation of human acts termed "moral theonomy"11 is primarily used. This means that "the highest norm of human life is the divine law-eternal, objective and universal-whereby God orders, directs and governs the entire universe and all the ways of the human community." 12 In a different place, the Council explains that "the norm of human activity is to reflect the genuine good of the human race in accord with the divine plan and will and allow man to pursue their entire vocation and fulfill it individually or socially." 13

It should also be noted here that in such an approach to the moral norm, the basic theses of the Christian faith are adopted, namely:

- There exists God who created the world and man.

- In every human being, God instilled a law which is recognizable by reason - this is the so-called natural law.

- The ability and objectivity of rational cognition has been weakened by the effects of the original sin; therefore, man is not always able to properly recognize or abide by this law.

- On account of the above, God has revealed the moral law. At the same time, He invites man to use the grace of which the sacraments are a principal source, so that he (man) could preserve this revealed God's law in his life. ${ }^{14}$

The Second Vatican Council also influenced the renewal of the approach of the Church toward the affairs of the modern world, including economy and entre-

10 Second Vatican Council, Gaudium et spes, 25; John Paul II, Redemptor hominis, 10.

11 The term "theonomy" means "divine law" as it is derived from the Greek terms "theos" = God, and "nomos" = law.

12 Second Vatican Council, Dignitatis humanae, 3.

13 Second Vatican Council, Gaudium et spes, 35.

14 Catechism of the Catholic Church, 1949-2051. Nagórny, "Moralność chrześcijańska." 
preneurship. ${ }^{15}$ The anthropological dimension was adopted as the basic criterion for analyses and evaluations, which was supplemented with the personalist approach: "all things present on earth should be directed towards man, constituting their center and peak." ${ }^{16}$ With regard to economic issues, the belief whereby man is "the creator, center and goal of the whole economic and social life" has become an axiom. ${ }^{17}$ Therefore, it can be argued that the Church promotes personalist ethic within its moral doctrine. Most of all, it emphasizes the dignity of the human person and proposes solutions in which man - while remaining free to pursue their ultimate goal - is not seen only as a tool of social, economic, and political structures, but as a subject.

This approach was especially close to Karol Wojtyła/John Paul II. For him, the human person is not only the optimal starting point for a universal interpretation of being, but also a metaphysical model of all human activity. From these fundamental assumptions, he derived three axioms: (1) the primacy of spirit over matter; (2) the primacy of "being" over "having"; (3) the primacy of the person over the thing. On the basis of the last principle - referring to Kant's second imperative ${ }^{18}-$ Karol Wojtyła formulated the personalist norm: "Whenever a person is the object of your activity, remember that you may not treat that person as only the means to an end, as an instrument, but must allow for the fact that he/she, too, has, or at least should have, distinct personal ends." 19 This principle is a normative expression of the recognition of the truth about man as a person and about the supra-utilitarian good.

The personalist norm is expressed in love, which is the affirmation of the value of man as the highest good. The commandment of love is so broad and capacious with respect to its extent and content that it ensures respect for every person and does not allow for their instrumental treatment. Thus, every human being, as a person, is entitled to love, that is, affirmation for themselves on the part of every other person. The source of the cognition of this norm is a properly formed and functioning conscience. Therefore, the personalist norm can be known and recognized by every person of good will.

The development of personalism not only enriched philosophy, theology, and Catholic social science, but also influenced the social and cultural changes of the last few decades. ${ }^{20}$ Personalism - as the direction of thought, especially in the sphere of Euro-Atlantic culture ${ }^{21}$ - is achieving an increasingly distinctive position among

15 Gocko, Kościół obecny w świecie; Percy, Entrepreneurship in the Catholic Tradition.

16 Second Vatican Council, Gaudium et spes, 12.

17 Second Vatican Council, Gaudium et spes, 63.

18 "So act that you treat humanity, whether in your own person or in the person of any other, always at the same time as an end, never merely as a means." (https://plato.stanford.edu/entries/persons-means/ \#UsinAnotButNotMereMean [access: 3.04.2021]; Kant, Uzasadnienie metafizyki moralności, 62).

19 Wojtyła, Love and Responsibility, 27.

20 Bartnik, "Personalizm."

21 Personalism as a system was actually initiated in the USA but based on the European (especially German) philosophy. This was done mainly by: George H. Howison (1834-1916), Borden P. Bowne (1847-1910), 
the multiplicity of scientific and cultural paradigms, ${ }^{22}$ although it should be noted that it is still insufficiently appreciated, for example, by business ethicists in Poland. ${ }^{23} \mathrm{Nev}$ ertheless, the assumptions of Christian ethics are taken into account in the research of business organizations around the world..$^{24}$ In this article, they are adopted as the hermeneutic key to the analysis of the ethical determinants of social entrepreneurship. Subsequently, it will allow us to make an attempt at the conceptualization of the professional ethics of social entrepreneurs in the spirit of Christian personalist ethic.

\section{Mission and Tasks of Social Entrepreneurs}

Entrepreneurship is a concept whose range of meaning should not be limited only to human activity in business. Contrary to common belief, entrepreneurship - as one of the human attitudes - focuses not only on the "pursuit" of profit, but in a broader sense, its essence lies in the inclination and capability of active and creative relating to the surrounding reality. Its main goal is to effectively overcome all challenges based on the available resources. Despite the immensely impressive civilizational and technological progress in the last decades, there still exist many social challenges in the world today, such as poverty or unemployment. Those who try to solve them in an entrepreneurial way are called social entrepreneurs. The organizations they manage use business models to execute a specific social mission. Thus, they offer alternative solutions to traditional charity and charitable activities. Social entrepreneurship does not work against or alongside the market but strives to use it as a space and at the same time a means of achieving social goals. ${ }^{25}$ There is increasing evidence that this approach is beneficial for people at risk of marginalization or social exclusion. ${ }^{26}$

The social entrepreneur is tasked with combining a social goal, set by a given non-profit organization, with an entrepreneurial approach closely related to business. Therefore, it is a person with a business-like mentality whose actions are ori-

Edgar Sh. Brightman (1884-1953), Ralph T. Flewelling (1871-1960), Peter A. Bertocci (1910-1989), Walter G. Muelder (1907-2004), Carol S. Robb (b. 1945). In Europe, on the other hand, Emmanuel Mounier (1905-1950) was approaching the personalism system with the "Esprit" school.

22 See for example, Jęczeń - Guzdek - Petryk, Personalizm w nauce i kulturze.

23 Zadroga, "Business Ethics in Poland."

24 See for example, Melé - Fontrodona, "Christian Ethics and Spirituality."

25 Such an approach seems to be a practical implementation of what the Catholic Church postulates with regard to economic life: "The development of economic activity and growth in production are meant to provide for the needs of human beings. Economic life is not meant solely to multiply goods produced and increase profit or power; it is ordered first of all to the service of persons, of the whole man, and of the entire human community. Economic activity, conducted according to its own proper methods, is to be exercised within the limits of the moral order, in keeping with social justice so as to correspond to God's plan for man" (Catechism of the Catholic Church, 2426).

Karwińska - Wiktor, Przedsiębiorczość i korzyści społeczne; Praszkier - Nowak, Przedsiębiorczość społeczna. 
ented toward solving social problems. To this end, they use a strategy typical of business projects, as well as innovation, creativity, and new technologies. Owing to their business competences and specific projects, they are able to create positive changes in a given community or social group, stimulate people to interact and build social capital based primarily on trust. In this sense, the social entrepreneur is often a visionary, social leader, political leader, and mentor transferring knowledge, skills, competences, as well as social values to his or her co-workers, most of whom are people at risk of social exclusion. ${ }^{27}$

The main tasks of the social entrepreneur include:

- identifying relatively permanent and inherently unfair conditions which lead to the exclusion or marginalization of social groups which are not able to solve a given problem or improve the existing situation on their own;

- identifying opportunities (chances) which can restore a fair balance in relation to the identified problem;

- undertaking specific projects that will create systemic solutions alleviating or eliminating a specific social problem, and which will provide better conditions for the functioning of a specific group, and even the whole society;

- basing in the process of implementing solutions, primarily on the potential of the interested parties. ${ }^{28}$

\section{Motivation and Vocation of Social Entrepreneurs}

The analysis of the literature on the subject and descriptions of good practices in the field of social entrepreneurship have led to the conclusion that social entrepreneurs are characterized by a strong internal motivation to engage in solving perceived social issues. These are, among others, problems such as unemployment, homelessness, and disability. Their main goal is the social activation and professional reintegration of those who are affected by this type of problem. ${ }^{29}$ Thus, the image of a social entrepreneur is characterized by "the will to serve" others. It is an approach with clear pro-social motives, which are expressed in practice by serving the poor and protecting the weak. ${ }^{30}$

The deepest source of this approach can be found in spiritual motives. Hence, social entrepreneurs should also perceive their commitment to other people,

\footnotetext{
Wronka-Pośpiech, “Cechy i kompetencje menedżera społecznego," 30.

Martin - Osberg, "Social Entrepreneurship," 29-39.

Praszkier, "Zwykli ludzie czy herosi?"

Nullens, "The Will to Serve"; Di Somma, "Protecting the Weak."
} 
most of all, in terms of a spiritual vocation. ${ }^{31}$ In his encyclical Caritas in veritate, Benedict XVI emphasizes that: "Every Christian is called to practice this charity, in a manner corresponding to his vocation and according to the degree of influence he wields $[\ldots]]^{\prime 32}$

True Christian faith always has social implications. The personal faith of social entrepreneurs should lead them to the development of social leadership skills. This, in turn, in the social dimension, should encourage them to:

- search for innovative solutions to problems which they notice in the social environment,

- improve social and economic structures so that every person, even the socially excluded, has the opportunity to participate in the work of creation,

- take responsibility for creating such an organization of work that will affirm the dignity of each employee.

Specific guidelines of the Church for Christian entrepreneurs and all other business men and women (people of good will) are contained in the document of the Pontifical Council "Iustitia et Pax" entitled The Vocation of the Business Leader. A Reflection..$^{33}$ It is a peculiar guide for entrepreneurs who feel called upon to take up the challenges (opportunities and threats) posed by modern economy, especially the business world. Its addressees are the leaders of market-oriented companies (international corporations, enterprises, family businesses), as well as the leaders of social economy entities (foundations, associations, social cooperatives, social enterprises). In the Foreword, Cardinal Peter K.A. Turkson and Bishop Mario Toso wrote that "business leaders are called upon to engage with the contemporary economic and financial world in light of the principles of human dignity and the common good." ${ }^{34}$

In light of the spiritual and moral message of the abovementioned document, it should be emphasized that Christian leaders of social entrepreneurship, responding to their vocation, should strive for the internal integration of faith and earthly life. This will prevent them from leading a "divided life" which separates the requirements stemming from faith from their daily work in the social economy sector. Internally integrated social entrepreneurs will be able (in the spirit of service) to take on the role of a leader in their organizations. They will be willing to share their skills and competences with others, they will shape their work environment imbued with

31 Pontifical Council for Justice and Peace, The Vocation of the Business Leader; Sirico, The Entrepreneurial Vocation; Novak, Business as a Calling. The words of Jesus Christ: "Everyone to whom much was given, of him much will be required, and from him to whom they entrusted much, they will demand the more" (Luke 12:48) are an exhortation for every Christian to undertake professional duties (according to personal talents) not only for the sake of self-interest (remuneration), but also for the benefit of others.

33 Pontifical Council for Justice and Peace, The Vocation of the Business Leader. 
a good atmosphere of mutual kindness and trust and will include their companies in the process of creating the common good.

Social entrepreneurs know that profit is essential to the development of any company. However, at the same time, they understand that "focusing exclusively on profit, a situation when it is produced by improper means and without the common good as its ultimate objective, brings about the risk of destroying prosperity and creating poverty." 35 Therefore, it is still necessary to remind that every business leader who accepts that the only criterion for operating in business is to maximize profits at all costs, runs the risk of committing the sin of idolatry, that is, making business a sort of a "golden calf." They are also threatened with the sins of pride and greed, resulting from the illusory sense of their own power (cleverness, intelligence, knowledge) as a source of financial success and the willingness to maintain and increase the achieved results without taking into account other criteria of sustainable socio-economic development. ${ }^{36}$ Meanwhile, the vocation of business leaders (especially in social enterprises) is not only to multiply and accumulate financial and physical capital, but also to develop human talents and moral virtues.

Some researchers, for example Sophie Bacq, Chantal Hartog and Brigitte Hoogendoorn, point out that the motives of social entrepreneurs can be "impurely altruistic." As a result, these authors go beyond the - almost taken-for-granted - moral image of social entrepreneurs as ethical persons. They particularly take a critical attitude toward the assumption that a strong focus on entrepreneurship is the source of an ethical approach. Thanks to their research, they presented evidence that the ethical problems of social entrepreneurs' result, among others, "from a frail entrepreneurial profile." ${ }^{37}$ Therefore, in addition to the pro-social internal motivation described above, social entrepreneurs need important professional competencies because even the noblest motives for action will not replace professionalism, necessary in every profession.

Martyna Wronka-Pośpiech, who has been conducting research on the characteristics and competencies of social entrepreneurs for many years, emphasizes that anyone managing a social enterprise should have broad horizons, be creative and courageous in action, and open to innovation. In her opinion, the following competencies seem to be particularly important to social entrepreneurs: (1) building a strategy that allows them to achieve the goals of their social enterprises, (2) managing relations with external stakeholders, (3) managing employees and volunteers, (4) managing finances, and (5) perceiving social economy in the world of social and economic relations. ${ }^{38}$

35 Benedict XVI, Caritas in veritate, 21.

36 Christ warns us: "Take care, and be on your guard against all covetousness, for one's life does not consist in the abundance of his possessions" (Luke 12:15).

37 Bacq et al. "Beyond the Moral Portrayal of Social Entrepreneurs."

38 Wronka-Pośpiech, "Cechy i kompetencje menedżera społecznego," 33-35. 
Another author, Teresa Piecuch, characterizing social entrepreneurs on the basis of the available literature on the subject, states that they are "leaders engaged in social initiatives, agents of social changes solving the most sensitive and difficult social problems. They are visionaries - they have good ideas and devote themselves completely (often at the cost of their own lives) to their implementation. They also have an excellent ability to enthuse others with their own initiatives, those who share their views and co-implement their ideas." ${ }^{39}$

Professionalization and growing competition in the social enterprise sector means that managers of these organizations must change from being passive administrators to active leaders. For this reason, as noted by Martyna Wronka-Pośpiech, social entrepreneurs "must acquire new skills and use new cognitive tools that will enable them to make rational managerial decisions. This is because leaders - on account of their knowledge and position - are expected to make decisions that have a significant impact on the achievements and results of the entire organization." ${ }^{40}$

While highlighting the role of leadership competences regarding social entrepreneurs, it should be recalled that numerous traditional studies on business leadership have developed with the assumption that business leadership can only be effective when it first of all aims at maximizing profits. ${ }^{41}$ Nowadays, there is a growing belief that good leadership means moral leadership. ${ }^{42}$ Moreover, there is growing interest $i^{43}$ spiritual leadership. Therefore, the issue of leadership in social enterprises should be described in greater detail, taking into account research trends of this type.

\section{Ethical Aspects of Leadership in Social Enterprises}

Taking into consideration the goals of social entrepreneurship, the theory of "Servant Leadership" (SL) is particularly interesting in this context. The creator of the Servant-Leadership model is Robert K. Greenleaf (1904-1990). His classic work on the subject ${ }^{44}$ is a collection of lectures and articles delivered for over 20 years. On the other hand, his groundbreaking essay on SL, entitled The Servant as Leader was published in $1970 .{ }^{45}$ The modern theory of SL goes back to the works of Greenleaf,

39 Piecuch, T., "Charakterystyka przedsiębiorców społecznych," 67.

40 Wronka-Pośpiech, "Cechy i kompetencje menedżera społecznego," 36.

41 Yukl, Leadership in Organizations; Rost, Leadership for the Twenty-First Century.

42 Ciulla, The Ethics of Leadership; Johnson, Meeting the Ethical Challenges of Leadership.

43 Dent et al., "Spirituality and Leadership"; Fry, "Toward a Theory of Spiritual Leadership"; Fry - Nisiewicz, Maximizing the Triple Bottom Line Through Spiritual Leadership.

44 Greenleaf, Servant Leadership.

45 It is worth adding that in 1964 Robert K. Greenleaf founded the Center for Applied Ethics, which later became the Greenleaf Center for Servant Leadership - www.greenleaf.org. 
who formulated its basic definition as follows: "The servant-leader is servant first ... It begins with the natural feeling that one wants to serve, to serve first. Then conscious choice brings one to aspire to lead." ${ }^{36}$ It is the will to serve that is the key point of the SL theory. Inge Nuijten emphasizes that "servant-leadership differs from other types of leadership in that it places the interests of those led above the self-interest of the leader." ${ }^{47}$

It should be noted that studies on leadership, which are part of social sciences, are based on a specific interpretation of the human person and social structures. ${ }^{48}$ Moreover, these anthropological and social assumptions are an inherent part of a given worldview, philosophical thought, or theological doctrine (religion). For example, it has been proved that there is an important relationship between the philosophy of personalism and SL. ${ }^{49}$ Hence, one can assume the existence of an equally important relationship between the Catholic theological thought and the SL theory because personalism - as already mentioned - is one of the most important philosophical sources for the contemporary Catholic theology. ${ }^{50} \mathrm{Also}$, the will to serve - as the foundation of selfless love of neighbor and building a community - is also the main moral imperative for the followers of Christianity (naturally including the Catholic faith).

Thus, the available knowledge on the spiritual and moral dimensions of the SL theory as a leadership concept can be effectively applied in the area of social entrepreneurship. SL is a concept that focuses not only on the social performance of entrepreneurial activity but in particular on the inner motivation: to serve in the first place. Therefore, the concepts of social entrepreneurship and SL overlap. Whereas the former corresponds to a specific form of entrepreneurship in which social performance takes precedence over earning profits, the latter additionally highlights the basic motivations of compassion, humility, and selflessness. Serving the common good combines both concepts. ${ }^{51}$ Obviously, the concept of SL, like any other model, has its limitations. Nevertheless, the explicit emphasis on the priority of the "will to serve" in this leadership concept can be remarkably inspiring, especially for social entrepreneurs.

Another principle of social enterprises is mindful leadership. This leadership style urges leaders to place humanity at the center of their business activities. Hence, a social entrepreneur as a "mindful" leader should act in accordance with practical wisdom, selflessness and compassion when making managerial decisions. "The moral core of mindful leadership, like that of servant leadership, involves serving others

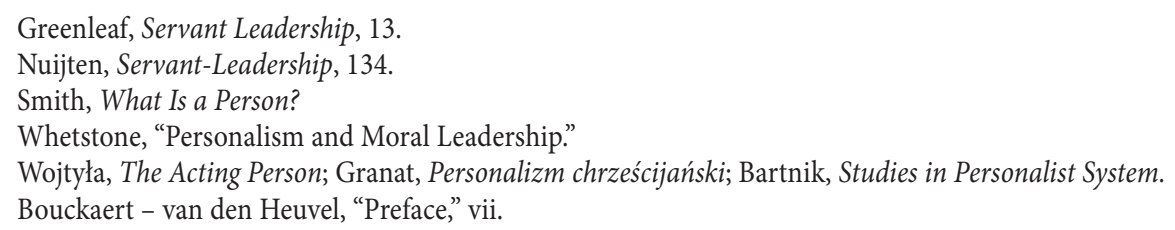


according to their real needs, and is centered on elements of love, caring, and inclusivity of others." ${ }^{52}$ Kevin Jackson emphasizes that

Mindfulness contributes important elements missing from received approaches to servant leadership: first, the inclination of a mindfulness approach to focus on internal states, beliefs, attitudes, and motivations - features which bear on the leader's inner motivation to care for a wide range of stakeholders beyond just «followers» and to create value for them for non-instrumental reasons; second, the inclination of a mindfulness approach to focus on ethics-in-practice in addition to merely theoretical treatment. ${ }^{53}$

\section{Ethical Principles and Moral Virtues of Social Entrepreneurs}

Various types of professional ethics usually belong to the domain of normative ethics, especially deontology, and therefore, they are most often concerned with duties, obligations, and strictly defined procedures of conduct. They primarily take the form of ethical codes for a given profession. Their elements can also be found in professional oaths and pledges. Fundamental ethical principles that underpin certain professional ethics should be closely related to the general mission which a given profession pursues in social life. The moral identity of a particular profession is also determined by primary values and moral virtues, which are important from the point of view of its social status. ${ }^{54}$ The presented discourse, therefore, prompts the question of what principles, values and virtues constitute the profession of a social entrepreneur.

Considering the paradigm of Christian personalist ethics, the fundamental moral principle for social entrepreneurs should be concern for respect of the personal dignity of every co-worker and recipient of their entrepreneurial activities. Being mindful that the essence of any ethical principle is to protect broadly understood good - your own good and the good of others ${ }^{55}$ - the ethics of social entrepreneurship should primarily safeguard impersonal interests as well as should be expressed in selfless help to people threatened by social exclusion.

Thus - the source and encapsulation of all moral obligations of social entrepreneurs - should be traced to the Gospel commandment to love your neighbor, especially the poor. ${ }^{56}$ However, it should be noted that social entrepreneurs cannot

52 Jackson, "Mindful Servant Leadership," 220.

53 Jackson, "Mindful Servant Leadership," 229.

54 Lewicka-Strzałecka, Etyczne standardy firm, 30-32.

55 The fundamental commandment of Christianity calls upon us to love our neighbor as we do ourselves see for example Mark 12:29-31.

56 See Matthew 25:31-36, as well as the monograph: Surmiak, Opcja preferencyjna na rzecz ubogich. 
make managerial decisions that unfavorably affect the enterprise and themselves in order to provide short-term help. In this way, they would not fulfil their basic obligations, i.e., profitable production of goods and services and preservation of workplaces for people from the so-called underprivileged groups in the open labor market. The measure of their professional achievements is not only the positive social effect, but also the positive economic effect of the undertaken activities because the completion of the adopted mission without profit is unfeasible. Therefore, a social entrepreneur should be a responsible person. Setting out goals and their attainment must be constantly accompanied by the sense of responsibility - not only for the enterprise itself but also for the social outcomes that this form of activity may yield in the community.

The role of a leader introducing good changes also requires prudence in making decisions. They should always be aimed at building the common good. These two recommendations constitute other norms which should shape the way in which a social entrepreneur thinks and acts. Moreover, contributing to the common good a leader of a social enterprise should also follow the principles of solidarity and subsidiarity, which can be viewed as further elements of the axiological core of social entrepreneurship.

Moreover, for a social entrepreneur freedom (independence) of action is certainly important. Of particular significance is the absence of pressure exerted by various types of institutions or interest groups. Such pressure could result in obstructing the proposed innovative solutions, which usually entail making difficult, rather unpopular decisions. Only extensive freedom in the process of implementing specific social projects will create the possibility of completing the mission of a social innovator or often even a pioneer in the introduction of creative solutions which facilitate positive socio-economic changes. This entails considerable responsibility for the decisions and actions they make. However, most of them are exceptionally strong personalities; they are brave, prudent individuals aware of the responsibility resting on their shoulders. ${ }^{57}$

When describing the ethical principles whose observance is an important aspect of social entrepreneurs' vocation, it is worthwhile to resort to the Catholic social teaching. The Church proposes to use the method: see - judge - promote: "Christian business leaders must be able to see this world in a way that allows them to make judgments about it, to build up its good and truth, to promote the common good and to confront evil and falsehood." 58

Consequently, it is important to inquire what principles should a social entrepreneur invoke as a Christian business leader regarding the perception of problems and devising ways of solving them. In light of Jesus Christ's teaching: "Everyone to

57 Piecuch, "Charakterystyka przedsiębiorców społecznych," 66.

58 Pontifical Council for Justice and Peace, The Vocation of the Business Leader, 16. 
whom much was given, of him much will be required, and from him to whom they entrusted much, they will demand the more" (Luke 12:48), it becomes obvious that entrepreneurs are especially called upon to undertake exceptionally important tasks not only for the sake of themselves but also for the benefit of others. At the starting point, they should have the conviction that "every Christian is obliged to practice this charity, in a manner corresponding to their vocation and according to the degree of influence they wield." ${ }^{59}$ Following their vocation, Christian business leaders (including social entrepreneurs) should strive for the inner integrity of faith and earthly life, thus not slipping into a "divided life," in which the obligations of faith are separated from everyday business activity. Business leaders of the highest personal integrity, showing the spirit of service, are able to effectively take the role of leaders in their organizations, willingly sharing their skills and competences with others: they create a work environment imbued with mutual kindness and trust and involve their own enterprises in creating the common good. They can become aware of the magnificence and uniqueness of their vocation by "building a productive organization," which expresses the continuation of the work of creation. An important part of the vocation of social entrepreneurship leaders is their practice of ethical social principles in the course of their business operations. ${ }^{60}$

The document of the Pontifical Council "Iustitia et Pax" The vocation of a Business Leader. A Reflection contains references to two fundamental principles of the Church's social teaching, i.e., respect for human dignity and pursuit of the common good. Moreover, it defines six practical principles of business: ${ }^{61}$

1) producing goods and services of good quality - truly serve, i.e., meeting genuine human needs and are not based on speculation;

2) showing solidarity with the poor and needy by being alert for opportunities and services at an appropriate level;

3) fostering the significance and dignity of human work - recognizing its subjective character ("work is for man, not man for work"62; employees are not only "human resources" or "human capital");

4) managing people in the spirit of the subsidiarity principle - providing opportunities for employees to contribute to the mission of the organization;

5) creative and productive management of the resources of the organization to ensure not only financial profitability, but also broadly understood economic prosperity (care for the natural environment and the good of the close and further environment of the organization);

\footnotetext{
59 Benedict XVI, Caritas in veritate, 7.

60 Pontifical Council for Justice and Peace, The Vocation of the Business Leader, 8-14

61 Pontifical Council for Justice and Peace, The Vocation of the Business Leader, 42.

62 John Paul II, Laborem exercens, 6.
} 
6) justice in relations with the stakeholders of the organization - just wage for employees, just prices for customers, just returns for owners, just prices for suppliers, just tax payments for the community. ${ }^{63}$

As John Paul II stated, the ultimate purpose of a business firm in light of the indicated principles "is not simply to make a profit, but is to be found in its very existence as a community of persons who in various ways are endeavouring to satisfy their basic needs, and who form a particular group at the service of the whole of society." ${ }^{\prime 4}$

With regard to the moral virtues that a social entrepreneur should have, one should first of all recall the cardinal virtues: prudence, justice, courage, and self-control. ${ }^{65}$ They mainly direct human behavior toward the implementation of the cardinal values integrally connected with human dignity, which include truth, goodness, justice, and love. ${ }^{66}$ In order to run a social enterprise, the following virtues are also necessary: creativity, the ease of building community bonds, practical realism, leadership skills, patience, perseverance, self-control, and humility. ${ }^{67}$

Moreover, the Church encourages entrepreneurs to be grateful for their talents, abilities, and skills and calls upon them to generously share their possessions with others in order to make the world a better place. The Church also requires them to be professional in their approaches to business, but at the same time the Church encourages them to respond to any doubts or fears that may arise from the perspective provided by the power of living faith, the power of supernatural hope, and the power of God's love. ${ }^{68}$

\section{Conclusions}

The discourse on social entrepreneurship shows that the phenomenon can be examined on the basis of two dimensions. The first one is external and concerns, among others, activities and/or organizational forms that entrepreneurs impart to their projects aiming at achieving social goals. The second dimension is related to the inner sphere and includes mental, moral, and spiritual determinants. It is from them, as from the root, that the specific shape of external initiatives in the field of social entrepreneurship grows. The development of a scientific theory embracing these two aspects is uneven. The vast majority of research focuses on the external

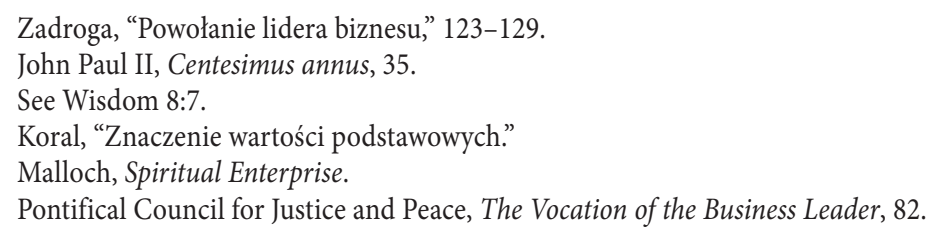


manifestations of social entrepreneurship. In turn, its internal conditions require undertaking scientific research from the point of view of various research perspectives. One of the most important ones is the axiological and ethical-normative perspective. This type of discourse in relation to social entrepreneurship, taking into account different types of normative ethics (and their limitations), has already been undertaken to some extent in the scientific literature, but the perspective of Christian personalist ethics has been used to a marginal extent.

The discourse presented in this article allows us to conclude that Christian personalist ethics makes a valuable and original contribution to the description of the normative determinants of social entrepreneurship. The concept of professional ethics of social entrepreneurs as compared with other ethical theories (e.g., deontonomism or utilitarian ethics), on the basis of which applied ethics can be formulated, is an attempt to overcome the legalistic and casuistic approach toward professional morality, manifested in the creation of deontological codes of ethics for a given profession. A human act and its evaluation, as well as the moral obligations which are derived from it, should not be separated from the person as the subject of moral action. Therefore, it is not only intended to recognize the good or the evil of a specific act, but also to understand and adequately assess the person performing this act. It is also important to reflect on who the person is, what motivates him to act, what he is called upon to do and what he becomes through his actions. ${ }^{69}$

Inspired by Christian faith and personalist ethics, social entrepreneurs should act in such a way that they will ultimately achieve both economic and social success acting in the spirit of service to God and the common good. The parable of the talents may be a biblical inspiration here (Matt 25:14-30). As leaders, they should manage their social enterprises with the conviction that they fulfil their principal vocation in life and Christian faith. Their motivation must go deeper than the need to maximize profits and satisfy personal aspirations. Drawing from the fruits of spiritual life and incorporating ethical principles and moral virtues in their lives, social entrepreneurs should not only harmoniously grow as persons and Christians, but also responsibly and effectively act for the benefit of other people (especially those at risk of social exclusion), stimulating local development and undertaking pro-ecological activities - in line with the idea of social entrepreneurship.

Naturally, the research perspective adopted in this paper, defined as "Christian personalist ethics," has its limitations. Since it should be emphasized that the number of theological sources typical of the Catholic tradition has been consciously limited. Hence, the axiological and normative premises of Catholic social teaching were basically accepted. In the future the research results can be analyzed by more comprehensively considering the fruits of ecumenical theological thought with respect to

John Paul II, Veritatis splendor, 29. 
Christian social mission and the biblical premises of the "revealed morality." A further direction of research may also include the issue of managing a social enterprise based on Christian moral values and principles.

Translated by Grzegorz Knyś

\section{Bibliography}

Bacq, S. - Hartog, C. - Hoogendoorn, B., „Beyond the Moral Portrayal of Social Entrepreneurs: An Empirical Approach to Who They Are and What Drives Them," Journal of Business Ethics 133/4 (2016) 703-718.

Bartnik, C.S., "Personalizm," Leksykon teologii fundamentalnej (eds. M. Rusecki et al.) (Kraków: Wydawnictwo M 2002) 911-914.

Bartnik, C.S., Studies in Personalist System (Lublin: Wydawnictwo KUL 2007).

Benedict XVI, "Caritas in veritate [Encyclical Letter]," Acta Apostolicae Sedis 101/8 (2009) 641-709.

Bouckaert, L. - van den Heuvel, S.C. (eds.), Servant Leadership, Social Entrepreneurship and the Will to Serve. Spiritual Foundations and Business Applications (Cham: Palgrave Macmillan 2019).

Bouckaert, L. - van den Heuvel, S.C., "Preface," Servant Leadership, Social Entrepreneurship and the Will to Serve. Spiritual Foundations and Business Applications (eds. L. Bouckaert - S.C. van den Heuvel) (Cham: Palgrave Macmillan 2019) v-viii.

Catechism of the Catholic Church (Città del Vaticano: Libreria Editrice Vaticana 1993).

Chell, E. et al., "Social Entrepreneurship and Business Ethics: Does Social Equal Ethical?," Journal of Business Ethics 133/4 (2016) 619-625.

Ciepielewska-Kowalik et al., Social Enterprise in Poland. Institutional and Historical Context" (ICSEM Working Papers 11; Liege: 2015).

Ciulla, J.B., The Ethics of Leadership (Belmont, CA: Thomson/Wadsworth 2003).

Cornelius, N. et al., "Corporate Social Responsibility and the Social Enterprise," Journal of Business Ethics 81 (2008) 355-370.

Dent, E.B - Higgins, M.E. - Wharff, D.M, "Spirituality and Leadership: An Empirical Review of Definitions, Distinctions, and Embedded Assumptions," The Leadership Quarterly $16 / 5$ (2005) 625-653.

Di Somma, E., "Protecting the Weak and Creating Community," Servant Leadership, Social Entrepreneurship and the Will to Serve. Spiritual Foundations and Business Applications (eds. L. Bouckaert - S.C. van den Heuvel) (Cham: Palgrave Macmillan 2019) 143-160.

Fry, L.W., "Toward a Theory of Spiritual Leadership," The Leadership Quarterly 14/6 (2003) 693-727.

Fry, L.W. - Nisiewicz, M.S., Maximizing the Triple Bottom Line Through Spiritual Leadership (Stanford, CA: Stanford Business Books 2013).

Gocko, J., Kościół obecny w świecie - posłany do świata. Teologiczno-społeczne aspekty posłannictwa Kościoła w świecie po Soborze Watykańskim II (Lublin: Wydawnictwo KUL 2003). 


\section{ADAM ZADROGA}

Granat, W., Personalizm chrześcijański. Teologia osoby ludzkiej (Poznań: Księgarnia św. Wojciecha 1985).

Greenleaf, R.K., Servant Leadership. A Journey into the Nature of Legitimate Power and Greatness (New York: Paulist Press 2002).

Hota, P.K. - Subramanian, B. - Narayanamurthy, G., "Mapping the Intellectual Structure of Social Entrepreneurship Research: A Citation/Co-citation Analysis," Journal of Business Ethics 166 (2020) 89-114.

Jackson, K., "Mindful Servant Leadership for B-Corps," Servant Leadership, Social Entrepreneurship and the Will to Serve. Spiritual Foundations and Business Applications (eds. L. Bouckaert - S.C. van den Heuvel) (Cham: Palgrave Macmillan 2019) 211-233.

Jęczeń, J. - Guzdek, P. - Petryk, A. (eds.), Personalizm w nauce i kulturze. Studia i rozprawy (Lublin: Wydawnictwo KUL 2020).

John Paul II, “Redemptor hominis [Encyclical Letter]," Acta Apostolicae Sedis 71 (1979) 257-324. John Paul II, “Laborem exercens [Encyclical Letter]," Acta Apostolicae Sedis 73 (1981) 577-647. John Paul II, “Centesimus annus [Encyclical Letter]," Acta Apostolicae Sedis 83 (1991) 793-867. John Paul II, “Veritatis splendor [Encyclical Letter]," Acta Apostolicae Sedis 85 (1993) 1133-1228. Johnson, C.E., Meeting the Ethical Challenges of Leadership: Casting Light or Shadow (Los Angeles, CA: Sage 2009).

Kant, I., Uzasadnienie metafizyki moralności (trans. M. Wartenberg) (Warszawa: PWN 1966).

Karwińska, A. - Wiktor, D., Przedsiębiorczość i korzyści społeczne: Identyfikacja dobrych praktyk w ekonomii społecznej (Ekonomia Społeczna Teksty 6; Warszawa: FISE 2008).

Koral, J., “Znaczenie wartości podstawowych w społeczeństwie obywatelskim,” Resovia Sacra 9-10 (2002-2003) 195-210.

Lewicka-Strzałecka, A., Etyczne standardy firm i pracowników (Warszawa: Wydawnictwo Instytutu Filozofii i Socjologii PAN 1999).

Mair, J. - Robinson, J. - Hockerts, K. (eds.), Przedsiębiorczość społeczna (trans. K. Dzięciołowicz) (Warszawa: Wydawnictwo Wyższej Szkoły Pedagogicznej TWP 2011).

Malloch, T.R., Spiritual Enterprise. Doing Virtuous Business (New York - London: Encounter Books 2008).

Martin, R.L. - Osberg, S., "Social Entrepreneurship: The Case for Definition," Stanford Social Innovation Review 5/2 (2007) 29-39.

Melé, D., - Fontrodona, J., "Christian Ethics and Spirituality in Leading Business Organizations: Editorial Introduction,” Journal of Business Ethics 145 (2017) 671-679.

Murzyn, D. - Pach, J. (eds.), Ekonomia społeczna między rynkiem, państwem a obywatelem (Warszawa: Difin 2018).

Nagórny, J., “Moralność chrześcijańska jako moralność nowego życia w Chrystusie," Vivere in Christo. Chrześcijański horyzont moralności. Księga pamiątkowa ku czci Księdza Profesora Seweryna Rosika w 65 rocznicę urodzin (eds. J. Nagórny - A. Derdziuk) (Lublin: Redakcja Wydawnictw KUL 1996) 87-116.

Novak, M., Business as a Calling. Work and the Examined Life (New York: Free Press 1996).

Nuijten, I., Servant-Leadership: Paradox or Diamond in the Rough? A Multidimensional Measure and Empirical Evidence (Diss. Erasmus University Rotterdam; Rotterdam 2009). 
Nullens, P., “The Will to Serve: An Anthropological and Spiritual Foundation for Leadership," Servant Leadership, Social Entrepreneurship and the Will to Serve. Spiritual Foundations and Business Applications (eds. L. Bouckaert - S.C. van den Heuvel) (Cham: Palgrave Macmillan 2019) 3-27.

Percy, A.G., Entrepreneurship in the Catholic Tradition (Lanham, MD: Lexington Books 2010). Piecuch, T., "Charakterystyka przedsiębiorców społecznych - przegląd literatury," Ekonomia Społeczna 10 (2014) 58-68.

Pontifical Council for Justice and Peace, The Vocation of the Business Leader. A Reflection, Vatican City: Pontifical Council for Justice and Peace 2014).

Praszkier, R., “Zwykli ludzie czy herosi? Motywacje przedsiębiorców społecznych,” Trzeci Sektor 4 (2005) 35-42.

Rost, J.C., Leadership for the Twenty-First Century (New York: Praeger 1993).

Praszkier, R. - Nowak, A., Przedsiębiorczość społeczna. Teoria i praktyka (Warszawa: Wolters Kluwer Polska 2012).

Second Vatican Council, "Gaudium et spes [The Pastoral Constitution on the Church in the Modern World]," Acta Apostolicae Sedis 58 (1966) 1025-1120.

Second Vatican Council, "Dignitatis humanae [Declaration on Religious Freedom]," Acta Apostolicae Sedis 58 (1966) 929-946.

Sirico, R.A., The Entrepreneurial Vocation (Grand Rapids, MI: Acton Institute 2001).

Smith, C., What Is a Person? Rethinking Humanity, Social Life, and the Moral Good from the Person Up (Chicago, IL: University of Chicago Press 2010).

Starnawska, M., „Przedsiębiorczość społeczna w społeczeństwie obywatelskim w Polsce, Studia BAS 44 (2015) 167-203.

Surmiak, W., Opcja preferencyjna na rzecz ubogich wyrazem miłości społecznej. Studium teologicznomoralne w świetle nauczania Jana Pawła II (Katowice: Księgarnia św. Jacka 2009).

Whetstone, J.T., "Personalism and Moral Leadership: The Servant Leader with a Transforming Vision," Business Ethics: A European Review 11/4 (2002) 385-392.

Wronka-Pośpiech, M., “Cechy i kompetencje menedżera społecznego," Ekonomia Społeczna 9 (2014) 29-37.

Wojtyła, K., Love and Responsibility (trans. H.T. Willetts) (San Francisco, CA: Ignatius Press 1993; Polish Edition: Miłość i odpowiedzialność. Studium etyczne [Kraków: Znak 1962]).

Wojtyła, K., The Acting Person (Dordrecht: Reidel 1979).

Yukl, G., Leadership in Organizations (New York - Englewood Cliffs, NJ: Prentice-Hall 1981).

Zadroga, A., "Business Ethics in Poland: a Metatheoretical Analysis," Annales. Ethics in Economic Life 20/8 (2017) 19-32.

Zadroga, A., "Methodological Premises of the Ethics of Social Entrepreneurship: From the Perspective of the Teachings of the Catholic Church," Rocznik Teologii Katolickiej 16/1 (2017) $141-151$.

Zadroga, A., "Powołanie lidera biznesu," Pastores 61/4 (2013) 123-129. 
